\title{
Growth of Northwest Iberian juvenile hake estimated by combining sagittal and transversal otolith microstructure analyses
}

\author{
C. Piñeiro ${ }^{a,{ }^{*}}$, J. Rey $^{b}$, H. de Pontual ${ }^{c}$ and A. García ${ }^{b}$ \\ a Instituto Español de Oceanografía, IEO, Apdo. 1552, 36200 Vigo, Spain \\ ${ }^{\mathrm{b}}$ Instituto Español de Oceanografía IEO, Malaga, Spain \\ c IFREMER, Laboratoire de Sclérochronologie des Animaux Aquatique STH/LASAA, BP 70, F-29280 Plouzané, \\ France \\ *: Corresponding author : C. Piñeiro, email address : carmen.pineiro@vi.ieo.es
}

\begin{abstract}
:
Daily growth of Atlantic juvenile hake from Northwest Iberia has been estimated employing a new approach combining analyses of transversal and sagittal sections of the otoliths along the ventral radius. Age of juvenile hake ranging from 3 to $25 \mathrm{~cm}$ collected during a spring 2002 survey was estimated. Somatic growth followed a power fit: Fish size $(\mathrm{TL})=3.3254^{\star} \mathrm{age}^{0.7336}\left(r^{2}=0.87, p<0.001\right.$, $n=76)$, yielding an average individual growth rate of $0.66 \mathrm{~mm} /$ day $( \pm 0.06)$. The growth model indicates that after a year's life a juvenile can reach $25 \mathrm{~cm}$. Otolith ventral radius ranged from 401 to $1842 \mu \mathrm{m}$ and daily increments were between 104 and 387. Fish growth and otolith growth were closely related $\left(r^{2}=0.92 p<0.001, n=76\right)$. These first results of daily growth rates for the Southern stock corroborate the fast-growth hypothesis of this species. The evolution of increment widths from hatch dates onwards reveals important seasonal growth peaks during July-August and OctoberNovember. A comparison with prior data and discussion is also presented in the light of recent work on hake juveniles and tagging-recapture experiences.
\end{abstract}

Keywords: Juvenile hake; Otolith microstructure; Daily growth; Seasonal variation; NW Iberian waters

\section{Introduction}

European hake (Merluccius merluccius) is a demersal finfish inhabiting Atlantic and Mediterranean waters. It is widely distributed in the Northeast Atlantic from Norway to Mauritania, being more abundant from the British Isles to the south of Spain (Casey and Pereiro, 1995). It is mainly found between 50 and $370 \mathrm{~m}$ depth though its distributional bathymetric range is from 30 to $1000 \mathrm{~m}$ (Domínguez-Petit, 2007). In the Western European fisheries hake is one of the most valuable and heavily exploited demersal species. In recent years the status of European hake stocks (Northern and Southern) has been cause for concern, particularly the Southern stock that is considered to be outside safe biological limits (ICES, 2007). However, the biology of hake is insufficiently known to make accurate predictions, and in particular little is known about growth, although such knowledge is critical for accurate stock assessment. 
2 European hake is a batch spawner (Murúa and Motos, 2006) with an indeterminate

3 fecundity. In Iberian waters it has a protracted spawning season that covers the whole

4 year, though most spawning activity occurs from December to July with, depending on

5 the year, a main peak between January and March and a secondary peak in June-July

6 (Dominguez-Petit, 2007). On the Galician and Cantabrian continental shelves there are

7 important nursery areas located where juveniles measuring 8-14 $\mathrm{cm}$ long have been

8 found from September to November (Sanchez and Gil, 1995, 2000).

9

10 The importance of growth prediction is reflected in the fast versus slow hake growth 11 debate that has been ongoing since the 1930s (Hickling 1933; Belloc, 1935). However 12 recent tagging experiments (de Pontual et al., 2003, 2006; Piñeiro et al., 2007), have

13 provided direct evidence supporting the fast-growth hypothesis, as anticipated by Belloc 14 (1935) and Bagenal (1954), which has implications on the management of the resource 15 (Bertignac and de Pontual, 2007).

17 Tagging small juvenile fish is difficult and has not been successful yet because of the 18 high natural mortality rate that occurs during early life stages. Therefore, an alternative 19 approach based on otolith microstructure analysis was developed to analyze growth 20 during the first year of life. Otolith incremental patterns have been validated for 21 European hake at daily level, directly in the Bay of Biscay (de Pontual et al. 22 unpublished data); indirectly in the Adriatic Sea (Arneri and Morales-Nin, 2000) and 23 from a larval rearing experiment in Norway (Morales-Nin et al., 2005). 
1 Growth studies on juvenile hake have been carried out in different areas of the

2 Mediterranean Sea (Morales-Nin and Aldebert, 1997; Morales-Nin et al., 1998; Arneri

3 and Morales Nin, 2000; Morales-Nin and Moranta, 2004; Belcari et al., 2006) and on

4 the northern stock in Atlantic waters (Kacher and Amara, 2005). Nevertheless, growth

5 estimations are still missing for hake of the so-called southern stock

6

7 The purpose of this study is to estimate, for the first time, the growth rate of juvenile

8 hake from northwestern Iberian waters which are home to an important nursery ground

9 (Southern stock, ICES Divisions VIIIc and IXa). The study is based on age estimates

10 from microincrement analyses of saggital and transversal otolith sections. Seasonal

11 growth is analyzed to improve the understanding of growth variability over time at the

12 juvenile life stage. The results obtained are compared with growth models reported by

13 other authors and discussed in the light of recent work carried out on juvenile of hake

14 and tag-recapture experiments.

16 Material and Methods

18 Juvenile hake were collected during a bottom trawl survey carried out in Spanish

19 Atlantic waters (Fig. 1) from the $22^{\text {nd }}$ to $30^{\text {th }}$ of April 2002 on board the $\mathrm{R} / \mathrm{V}$ "Cornide

20 de Saavedra”. The sampling scheme was randomly stratified according to depth and

21 geographical criteria (Sanchez et al., 1994, Sanchez and Gil, 2000). Hauls were

22 performed during daylight hours at a depth range of $40-325 \mathrm{~m}$. Sex, catch date and

23 total length ( $\pm 1 \mathrm{~mm}$ ) of fish were recorded on board, while otoliths (sagittae) were

24 carefully removed from five specimens by length class and stored dry in vials for

25 subsequent analysis in the laboratory. The terminology used for otolith sections is based 
1 on the glossary edited by Panfili et al., (2002).

2

3 A total of 157 pairs of otoliths were prepared from individuals between 3 and $25 \mathrm{~cm}$

4 (TL) long. Otoliths were embedded in polyester resin. Thin transversal sections (TS)

5 were obtained from the right otoliths $(\mathrm{N}=108)$ using an ISOMET saw machine.

6 Sections were ground with sandpaper between 400 and $1200 \mu \mathrm{m}$ and polished with a

7 graded series of aluminium oxide of 3,1 and $0.3 \mu \mathrm{m}$ until thin slides with clear

8 microincrement sequence along the ventral axis were obtained. The left otoliths $(\mathrm{N}=$

9 49) were ground equally on both sides along sagittal plane (SS) until the central zone

10 (CZ) increments were totally readable from the nucleus to the edge of accessory growth

11 centers.

13 Age interpretation was carried out using a light microscope connected to a video camera

14 that projects a live image of the otolith using the Image Analysis System OTO v3

15 software designed by Andersen and Moksness (1988). Increments were counted and

16 increment widths measured at magnifications from X250 to X1000 where the greatest

17 magnification corresponded to the core region (SS).

19 On TS, counts and measures were made along the ventral axis between the edge of the central opaque zone (COZ) and the otolith edge (Fig. 2). This otolith axis has been used

21 for decades for macrostructural interpretation (Piñeiro and Sainza, 2003) and has been

22 therefore chosen as the reference axis to undertake daily increment counts. To ensure

23 that the same axis was used in both sections, SS counting was done throughout the

24 ventral axis from the first discernible increment to the boundary with the accessory contiguous growth center. A linear relationship between the number of increments and 
1 the radius of $\mathrm{CZ}$ was obtained from the SS. This relationship was applied to estimate

2 the number of increments within COZ on TS. Thus, the age estimation was a 3-step

3 process: 1 ) counting increments on TS from the edge of the central opaque zone to the

4 otolith margin (Fig. 2c), 2) estimating the number of microincrements deposited in the

5 CZ from the above relationship and 3) adding both estimates to obtain the total age. To

6 assess age estimation errors the average percentage of error (APE) (Beamish and

7 Fournier, 1981) and CV were calculated for the two readings made on TS.

8

9 Assuming that no age differences occur between right and left otoliths, the growth

10 through the life cycle of juvenile hake was fitted to a power function. Individual growth

11 increments of each larva were estimated from the derivative of the power function of

12 growth and corrected using residuals of estimated to observed sizes as described in

13 Ramirez et al. (2001).

15 Changes in increment width under transmission light microscopy of transversal sections

16 were examined in relation to the presence of translucent and opaque zones in order to

17 understand the seasonal growth variation pattern.

19 Results

21 A total of 76 transversal and 27 sagittal otolith sections could be read, while the rest

22 were discarded due to over-polishing or an imprecise increment pattern (Table 1). The

23 fish and otolith size, number of increments and the total radius recorded are summarized

24 in Table 2. The saggital and transversal sections have a different appearance. The central region of SS is characterized by a core surrounded by accessory growth centers, 
1 with individual increments being almost contiguous across the growth zones and

2 corresponding to different points of nucleation (Fig. 2a). This complex structure appears

3 as an opaque zone (COZ) on TS with poorly defined increments difficult to interpret

4 (Fig. 2 b). From the COZ edge, increments tend to be wider and regularly spaced on the 5 ventral axis (Fig. 2b, c, d).

6

$7 \quad$ Sagittal section

8

9 The core and accessory growth centers were completely formed in individuals at a 10 minimum size of $3 \mathrm{~cm}$ TL, (Fig. 2a). Radius measurements along the ventral axis to the 11 accessory growth centers were highly variable due to its irregularly shaped border. 12 Thus, radius measurements to the accessory growth centers were independent of fish 13 size.

15 The number of increments in the CZ ranged from 38 to 69 , with a mean value of 51 ( \pm 16 8.0) and a radius range of $89-212 \mu \mathrm{m}$ with a mean value of $141 \mu \mathrm{m}( \pm 31.6)$ (Table 2$)$.

17 Increment counts started from a first check observed at $24 \mu \mathrm{m}( \pm 3.9)$, presumably 18 corresponding to a "first feeding check" (FFC). From this check onwards visible 19 increments appeared with a progressively wider pattern $(1-2 \mu \mathrm{m})$ from the FFC to the 20 edge of accessory growth centers, with a mean value of $3 \mu \mathrm{m}( \pm 0.9)$ and reaching a 21 maximum value of $4 \mu \mathrm{m}$ at 40 increments (Fig. 3). From this point increment widths 22 decrease gradually to $3 \mu \mathrm{m}$.

24 The ventral radius of CZ vs increment counts showed strong relationships both by linear 25 and power functions fixing an intercept at $16.3 \mu \mathrm{m}$ as hatch check reported by Palomera 
1 et al. (2005) (Fig. 4). Nevertheless, the power function has been considered more

2 adequate to explain the early life otolith growth of this species

3 (Radius $=16,3+0,653978 *$ age ${ }^{1,33394} ; \mathrm{R}^{2}=0,734$ ).

4

5 Transversal section

6

7 The radius of ventral axis in TS ranged from $400-1842 \mu \mathrm{m}$ with a mean value of

$81211 \mu \mathrm{m}( \pm 367.8)$ (Table 2$)$. From the COZ edge, TS showed on the ventral axis, clear

9 increment sequence with an average width of $6 \mu \mathrm{m}( \pm 1.6)$. Sequences of wide and

10 narrow increment widths viewed under transmitted light at small magnification appear

11 as translucent and opaque bands (see Fig. 2c). The number of increments observed

12 from the COZ to the otolith edge ranged from 46 to 331. The APE and CV obtained

13 from the readings were 4.5 and 1.3 , respectively.

14

15 Fish growth and otolith growth are linearly correlated as indicated by the relationship 16 between otolith ventral radius in the TS and fish total length $(y=0.1035 x+50.019$;

$\left.17 \mathrm{r}^{2}=0.92, \mathrm{p}<0.001 ; \mathrm{n}=76\right)$. This allows fish size to be inferred from otolith size.

Growth model

22 The sum of estimates of SS and TS sections provide age estimates of the fish considered

23 in this study. The estimated age-length relationship was best explained by a power fit

24 whose origin intercepts at 0 , which would lead to a juvenile size of $25.2 \mathrm{~cm}$ at one year

25 (Fig. 5). No significant difference was observed when introducing a biological intercept 
1 at $2.5 \mathrm{~mm}$, size at hatch according to Palomera et al., (2005). Individual growth

2 increments show a significant decreasing trend with age (Fig. 6), which overall

3 averaged is $0.66 \mathrm{~mm} /$ day $( \pm 0.06)$.

4

5 Seasonal growth

6

7 Dating increments backwards from the most recent that coincide with capture date to

8 the COZ area, increment width ostensibly varied with time (Fig. 7), corresponding to

9 seasonal growth pattern. Two seasonal peaks of high growth are observed 10 corresponding to July-August and October-November, when increment widths are

11 greater than $6 \mu \mathrm{m}$. During the months of March-April and September, increment widths

12 decrease substantially to widths measuring around $4 \mu \mathrm{m}$. Therefore, juvenile growth

13 shows a seasonal trend where growth slows down in spring and early autumn (width $<6$

$14 \mu \mathrm{m})$ and increases in summer and winter.

15

16 Discussion

17

18 To understand the process of growth through the juvenile life cycle it was considered 19 important to gain insight of increment formation and deposition in early larval stages.

20 Since larval growth studies on European hake are at present rather scarce due to their

21 usually low catch of larvae by plankton gear (Palomera et al., 2005; Alvarez and

22 Cotano, 2005) on European hake from Mediterranean and Atlantic waters, this study

23 allows us to infer larval growth pattern from the interpretation of juvenile otoliths. 
1 Larval otoliths (sagittae) are disc shaped and, as they evolve over time, become

2 increasingly asymmetrical and gain complexity with the formation of accessory growth

3 centers until they reach a point at which age estimation of juveniles is difficult. The

4 approach used in this study attempts to overcome this issue by combining age

5 estimation from saggital and transversal planes to estimate the age of an individual.

6

7 Generally, it is assumed that increment formation in hake starts at hatching (Wright et 8 al., 2002,). The studies of Palomera et al. (2005) and Alvarez and Cotano (2005)

9 describe a dark spot in the center of the sagitta forming a clear check around it that they 10 attribute to a hatch check at a distance of 16.3 and $15.7 \mu \mathrm{m}$, respectively. These authors 11 observe a number of intermediate increments before the next check formation (4-6: 12 Alvarez and Cotano, 2005; 4-5: Palomera et al., 2005), which presumably corresponds 13 to the FFC, practically coincident with Bjelland and Skiftesvik (2006) who found that 14 hake larvae start first feeding at 6 days after hatch from a larval rearing experiment. The 15 first discernible increment observed on our SS was found at a mean distance of $24 \mu \mathrm{m}( \pm$ 16 3.9) from the core. From the relationship of $\mathrm{CZ}$ radius and SS increment counts in 17 which $16.3 \mu \mathrm{m}$ is assumed as hatch check, after 6 days we would find the FFC at $18 \quad 23.5 \mu \mathrm{m}$, in agreement with our assumed FFC.

20 Formation of the CZ and accessory growth centers are attributed to the pelagic life of 21 the larval stage of hake and recruitment to the bottom (Morales-Nin and Aldebert, 1997; 22 Arneri and Morales-Nin, 2000). The pelagic phase estimates from our observations (51士 238 days) are within the temporal range found by other studies (see Table 3), such as the 24 work of Belcari et al, (2006), but slightly lower than that reported by Morales-Nin and 25 Moranta (2004) on Mediterranean hake, and greater than that reported for Atlantic hake 
1 by Katcher and Amara (2005). These differences may be due to either the different

2 methodological approaches and/or to site dependent growth characteristics of hake

3 living in different environmental conditions.

4

5 Larval otolith analyses also show differences in maximum age estimates of hake larvae

6 between the Atlantic and Mediterranean (Alvarez and Cotano, 2005; Palomera et al.

7 2005), but these studies did not consider the whole early life history corresponding to

$8 \quad$ CZ formation.

9

10 The TS used to account for the juvenile phase presented particularly clear sequence of 11 microincrements (Fig. 2d) which at a macroscopic scale constituted successive wide 12 opaque zones (OZ) and narrower translucent zones (TZ). The latter corresponds to 13 either seasonal growth structures or fish specific responses to endogenous or 14 environmental factors (Courbin et al., 2007).

16 This plane of sectioning was chosen in this study because sagittal and frontal sections 17 did not allow accounting for the entire fish life (from the core to the edge) due to 18 curvilenar growth of hake otoliths in respectively the distal-proximal and antero19 posterior axis. The choice of a common interpretation axis between SS and TS (Fig. 2)

20 allowed a complete reconstruction of the life history on the assumption of left-right 21 symmetry generally fulfilled except in flatfish and catfish (Wright et al., 2002).

23 The measurement trajectory allows measuring the overall otolith ventral radius and 24 estimating the number of increments, while the relationship between the ventral radius 
1 of the TS is strongly correlated with fish length $\left(\mathrm{R}^{2}=0.92, \mathrm{p}<0.001\right)$ and therefore allows

2 a reliable estimation of fish size from otolith size.

4 Juvenile hake size showed clear exponential growth with the approach undertaken in

5 this study. The relationship is supported by a strong relationship between otolith size,

6 measured by the ventral radius, and daily increment counts which were highly

7 correlated with linear and power fits. However, we consider that the power model

8 provides a better description of otolith growth $\left(r^{2}=0.92 ; \mathrm{p}<0.001\right)$.

10 Averaged individual growth rates $(0.66 \mathrm{~mm} / \mathrm{day} \pm 0.06)$ were high and the growth 11 model indicates that at one year juvenile hake may attain $25.2 \mathrm{~cm}$. These values are 12 higher than most of the reported ones (Table 3), although they are in line with recent 13 estimations by Morales-Nin et al. (2005), and Kacher and Amara (2005) which defend 14 the fast-growth hypothesis. Furthermore, recent tag-recapture experiments provided 15 direct evidence for the fast growth hypothesis (de Pontual et al., 2006; Piñeiro et al., 16 2007), showing that NE Atlantic hake (M. merluccius) may reach $25 \mathrm{~cm}$ TL at the end 17 of the first year, instead of the $20 \mathrm{~cm}$ TL estimated from an internationally agreed age estimation method (Piñeiro and Saínza, 2003).

20 Growth studies based on otolith microstructure analysis have produced great 21 discrepancies in the estimated growth rates in the juvenile phase and consequently on 22 the size attained at the end of the first year of life. The highest daily growth rates (0.71$230.74 \mathrm{~mm} /$ day) were found in Atlantic hake (Kacher and Amara, 2005) which would 24 yield a juvenile TL of $23.8 \mathrm{~cm}$ at the end of a first year, while lower estimates have been 25 obtained in the Mediterranean (see Table 3). These differences may be due to various 
1 factors such as geographical locations, period of sampling and methodological 2 approaches.

4 The method employed in this study allows a unidirectional linear measurement path for

5 daily age interpretation, as recommended by Campana (1992). The main difficulty in 6 age estimation is found in the transition area between the $\mathrm{CZ}$ and the prisms of 7 accessory growth centres.

8

9 Analysis of otolith microstructure of the ventral axis indicated a variation of increment 10 widths showing seasonal growth variations. There is a decrease in growth in spring and 11 to a lesser extent in early autumn (width $<6 \mu \mathrm{m}$ ), while there are more stable growth 12 rates in winter and summer. Atlantic hake therefore follows a series of pulses of varying 13 growth intensity throughout the year as also reported for Mediterranean hake (Morales 14 and Moranta, 2004) and even undergoing a series of growth decreases during their first 15 year of life in the Atlantic and Mediterranean hake (Piñeiro and Pereiro, 1993; Morales16 Nin and Aldebert, 1997). The microstructural examination of increment width 17 variations with time of this study confirms hake growth variability.

19 In conclusion, we applied a novel approach involving TS and SS microstructural 20 analysis to estimate the growth of juvenile hake. The proposed approach will be useful 21 for the comparison of structural patterns at micro and macroscopic scales. Such analyses 22 are required for a better understanding of the typology of hake otolith macrostructure in 23 relation to the biological meaning and mechanisms (endogenous and environmental) 24 that control increment deposition. This approach also provides a new framework for the 
1 development of an alternative method of age estimation of this species as the current

2 one has been shown to be inaccurate (de Pontual et al., 2006).

3

4 Our study indicates that, during their first year of life, hake grow at a faster rate than

5 commonly accepted. Estimation of hake size at one year is in agreement with the hake

6 growth model derived from tag-recapture data in both hake stocks (de Pontual et al., 7 2006; Piñeiro et al., 2007).

8

9 Such results are of real interest as underestimation of growth has implications stock 10 assessment and management. As has been demonstrated for hake northern stock 11 (Bertignac and Pontual, 2007), bias in estimating age affects the absolute levels of 12 fishing mortality and stock biomass estimates, and also impacts on the predicted trend 13 in SSB indicating that the stock may be more reactive to any change such as for 14 instance fishing level, which affects medium and long term forecasts.

\section{Acknowlegments}

17 We thank all the participants in the survey CARDEM 02 on board the RV Cornide de 18 Saavedra from which the otolith samples were obtained. We especially want to thank F. 19 Saco for her technical assistance the preparation of otolith sections. Finally, we wish to 20 thank F. Velasco for providing the map and helpful comments on the manuscript and B.

21 Stobart for improving the English of this paper.

\section{References}


1 Andersen, T., Moksness. E., 1988. Manual for reading daily increments by the use of a

2 computer program. Flødevigen Meldingen 4. Directorate of Fisheries. Flødevigen

3 Biological Station. Arendal.

4

5 Álvarez, P., Cotano, U., 2005. Growth, mortality and hatch-date distributions of 6 European hake larvae, Merluccius merluccius (L.), in the Bay of Biscay. Fish. Res. 76, $7 \quad 379-391$.

8

9 Arneri, E., Morales-Nin, B., 2000. Aspects of the early life history of European hake 10 from the central Adriatic. J. Fish Biol. 56(6), 1368-1380.

12 Bagenal, T.B., 1954. Growth rate of the hake (Merluccius merluccius L.) in the Clyde 13 and other Scottish areas. J. Mar. Biol. Assoc. U.K., 33, 69-95.

Belcari P., Ligas, A., Viva C., 2006. Age determination and growth of juveniles of the 16 European hake, (Merluccius merluccius L.,1758). Fish. Res. 78, 211-217.

18 Belloc, G., 1935. Etude monograhique du merlu Merluccius merluccius L.. 3ème partie. 19 Rev. Trav. Off. Pêches marit. 8, 145-202.

21 Bertignac, M., de Pontual, H., 2007. Consequences of bias in age estimation on 22 assessment of the northern stock of European hake (Merluccius merluccius) and on management advice. ICES J. Mar. Sci. 64, 981-988. 
1 Beamish, R. J., Fournier, D. A., 1981. A method for comparing the precision of a set of

2 age determinations. Can. J. Fish. Aquat. Sci., 38, 982-983.

3

4 Bjelland, R.M., Skiftesvik, A.B., 2006. Larval development in European hake 5 (Merluccius merluccius L.) reared in a semi-intensive culture system. Aquacult. Res. $6 \quad 37,1117-1129$.

7

8 Campana, S. E., 1992. Measurement and interpretation of Microstructure of Fish

9 Otoliths. In: D.K. Stevenson. and S.E. Campana (eds) Otolith microstructure 10 examination and analysis. Can. Spec. Publ. Fish. Aquat. Sci. 117, 59-71

12 Casey, J., Pereiro, F.J., 1995. European hake (M. merluccius) in the North-east Atlantic. 13 In: Alheit, J., Pitcher, T. J. (Eds.), Hake, Biology, Fisheries, and Markets. Chapman \& 14 Hall, London. pp. 125-147.

16 Courbin N., Fablet, R., Mellon, C., de Pontual, H., 2007. Are hake otolith 17 macrostructures randomly deposited? Insights from an unsupervised statistical and 18 quantitative approach applied to Mediterranean hake otoliths. ICES J. Mar. Sci. 64, $19 \quad 1191-1201$

21 de Pontual, H., Bertignac, M., Battaglia, A., Bavouzet, G., Moguedet, P., Groison, A.L., 22 2003. A pilot tagging experiment on European hake (Merluccius merluccius): methodology and preliminary results. ICES J. Mar.Sci. 60, 1318-1327. 
1 de Pontual, H., Groison, A.L., Piñeiro, C., Bertignac, M., 2006. Evidence of

2 underestimation of European hake growth in the Bay of Biscay, and its relationship with

3 bias in the agreed method of age estimation. ICES J. Mar.Sci. 63, 1674-1681.

4

5 Domínguez- Petit R., 2007. Study of Reproductive Potential of Merluccius merluccius 6 in the Galician Shelf. Doctoral Thesis. University of Vigo (Spain). 253pp.+ xxii.

7

8 Hickling, C. F., 1933. The natural history of hake. 4. Age determination and growth 9 rate.UK Ministry of Agriculture, Fisheries and Food, Investigation Series $10 \quad 2,13(2) .120 p p$.

11

12 ICES., 2007. Report of the Working Group on the Assessment of Southern Shelf Stocks 13 of Hake, Monk and Megrim. ICES CM2007/ACFM:21. 700 pp.

15 Kacher, M., Amara, R., 2005. Distribution and growth of 0-group European hake in the 16 Bay of Biscay and Celtic Sea: a spatial and inter-annual analyses. Fish. Res. 71, 37317378.

18

19 Morales-Nin, B., Aldebert, Y., 1997. Growth of juvenile Merluccius merluccius in the 20 Gulf of Lions (NW Mediterranean) based on otolith microstructure and length 21 frequency analysis. Fish. Res. 30, 77-85.

23 Morales-Nin, B., Torres. G.J. Lombarte A.and Recasens L., 1998 .Otolith growth and 24 age estimation in the European hake. J. Fish Biol. 53,115-1168. 
1 Morales-Nin, B., Moranta, J., 2004. Recruitment and post-settlement growth of juvenile

2 Merluccius merluccius on the western Mediterranean shelf. Sci. Mar. 68 (3),339-409.

3

4 Morales-Nin, B., Bjelland, R.M., Moksness, E., 2005. Otolith microstructure of a 5 hatchery reared European hake (Merluccius merluccius). Fish. Res. 74, 300-305.

6

7 Murúa, H. Motos. L., 2006. Reproductive strategy and spawning activity of the

8 European hake (Merluccius merluccius L.) in the Bay of Biscay. J. Fish Biol. 69, 128891303.

10

11 Palomera, I., Olivar M.P., Morales-Nin, B., 2005. Larval development and growth of 12 the European hake Merluccius merluccius in the northwestern Mediterranean. Sci. Mar. 13 69(2), 251-258.

14

15 Panfili, J., Meunier, F.J., Mosegaard, H., Troadec, H., Wright, P.J., Geffen A.J., 2002. 16 Glossary. In: Manual of Fish Sclerochronology, pp. 373-384. Panfili, J., Pontual, H. 17 (de)., Troadec H., Wright P.J. (eds), 2002. Brest, France: Ifremer-IRD Co-edition, 464 18 p.

19

20 Piñeiro, C.G., Pereiro, J. A., 1993. Study on juvenile growth pattern of European hake 21 (Merluccius merluccius L.) using whole otoliths and length frequency distributions from 22 commercial catches and fish surveys. ICES C.M. 1993/G: 12, 14 pp. 
1 Piñeiro, C., Saínza, M., 2003. Age estimation, growth and maturity of the European

2 hake, (Merluccius merluccius Linnaeus, 1758) from Iberian Atlantic waters. ICES J.

3 Mar. Sci. 60, 1086-1102.

4

5 Piñeiro, C., Rey, J., de Pontual, H., Goñi, R., 2007. Tag and recapture of European hake

6 (Merluccius merluccius L.) off the Northwest Iberian Peninsula: First results support

7 fast growth hypothesis. Fish. Res. 88, 150-154.

8

9 Ramirez, T., Cortés, D., García, A., 2001. Growth of Alborán Sea sardine larvae

10 estimated by otolith microstructure, nucleic acids and protein content. J. Fish Biol. 59, $11 \quad 403-415$.

12

13 Riis-Vestergaard, J., Velasco, F.,Hill, L., Olaso, I., 2000. Food consumption of 14 European hake (Merluccius merluccius) estimated by application of a bionenergetics 15 model: Is the growth of hake underestimated? ICES C.M. 2000/Q:12 12 pp.

17 Sánchez, F., 1994. Campaña de evaluación de recursos pesqueros “Demersales0991”. 18 Inf. Téc. Inst. Esp. Oceanog., 155, 51pp.

19

20 Sánchez, F., Gil, J., 1995. Influencia de anomalías térmicas de mesoescala sobre la 21 distribucion de peces demersales. In: Actas del IV Coloquio Internacional de 22 Oceanografía del Golfo de Vizcaya, pp.49-54.Ed. by O. Cendrero, and I. Olaso. Inst. 23 Esp. de Oceanografía, Santander. 
1 Sánchez F., Gil, J., 2000. Hydrographic mesoscale structures and Poleward Current as a

2 determinant of hake (Merluccius merluccius) recruitment in southern Bay o Biscay.

3 ICES Jour. Mar. Sci. 57, 152-170.

4

5 Wright, P. J., Panfili, J., Folkvord, A., Mosegaard, H., Meunier, F. J., 2002. Direct 6 validation. In: Manual of Fish Sclerochronology, pp. 114-127. Ed. by J. Panfili, H. de 7 Pontual, H. Troadec, and P. J. Wright. Ifremer-IRD Co-edition, Brest, France.

8

9 Wright, P. J., Panfili, J., Morales-Nin, B, Geffen, F. J., 2002. Otoliths. In: Manual of 10 Fish Sclerochronoloy, pp. 31-57. Ed. by J. Panfili, H. de Pontual, H. Troadec, and P. J. 11 Wright. Ifremer-IRD Co-edition, Brest, France. 


\begin{tabular}{ccc}
\hline TL $(\mathrm{cm})$ & SS & TS \\
\hline$<5$ & 1 & - \\
$5-10$ & 1 & 3 \\
$11-15$ & 8 & 27 \\
$16-20$ & 14 & 26 \\
$21-25$ & 3 & 20 \\
\hline Total & 27 & 76 \\
\hline
\end{tabular}

Table 1 .- Number of sagittal (SS) and transversal section (TS) otoliths analyzed by fish length class. 


\begin{tabular}{cccccc} 
SS & $\begin{array}{c}\text { Fish } \\
\text { Length } \\
(\mathrm{TL} ; \mathrm{mm})\end{array}$ & $\begin{array}{c}\text { First ring } \\
(\mu \mathrm{m})\end{array}$ & $\begin{array}{c}\text { Radius CZ } \\
(\mu \mathrm{m})\end{array}$ & $\begin{array}{c}\text { Increment } \\
\text { width } \\
\mathrm{CZ}(\mu \mathrm{m})\end{array}$ & $\begin{array}{c}\text { Daily } \\
\text { Increments } \\
\mathrm{CZ}\end{array}$ \\
\hline Mean & 163 & 24 & 141 & 3 & 51 \\
range & $32-229$ & $15-31$ & $89-212$ & $1-4$ & $38-69$ \\
SD & 41.7 & 3.9 & 31.6 & 0.9 & 8.0 \\
\hline
\end{tabular}

\begin{tabular}{ccccccc} 
TS & $\begin{array}{c}\text { Fish } \\
\text { Length } \\
(\mathrm{TL} ; \mathrm{mm})\end{array}$ & $\begin{array}{c}\text { Total } \\
\text { VR }(\mu \mathrm{m})\end{array}$ & $\begin{array}{c}\text { VR } \\
\text { of COZ } \\
(\mu \mathrm{m})\end{array}$ & $\begin{array}{c}\text { VR } \\
\text { without COZ } \\
(\mu \mathrm{m})\end{array}$ & $\begin{array}{c}\text { Daily } \\
\text { Increm. } \\
\text { without COZ }\end{array}$ & $\begin{array}{c}\text { Total } \\
\text { Daily } \\
\text { Increm. }\end{array}$ \\
\hline Mean & 175 & 1211 & 142 & 1069 & 173 & 224 \\
range & $93-256$ & $400-1842$ & $76-208$ & $230-1707$ & $46-331$ & $104-387$ \\
SD & 39.7 & 367.8 & 31.9 & 371.2 & 66.9 & 65.9 \\
\hline
\end{tabular}

Table 2.- Summary of statistics of data measurements obtained from the analysis of sagittal section (SS) and transversal section (TS) otoliths: fish length, first ring observed, radius of CZ $(\mu \mathrm{m})$, increment width of CZ $(\mu \mathrm{m})$, daily increments of CZ, ventral radius (VR, $\mu \mathrm{m})$ of $\mathrm{COZ}$, total ventral radius, daily increments without $\mathrm{COZ}$ and total daily increments. 
Table 3. Summary table of daily growth data obtained by different authors in different areas: Growth rate (GR), Central zone (CZ) and its daily growth increments (DGI), mean length at the first year (ML), otoliths sampled and fish length (FL) range and geographical area.

\begin{tabular}{|c|c|c|c|c|c|c|}
\hline Author & GR & $\begin{array}{c}\text { CZ size } \\
\varnothing=\text { diameter } \\
\circledR=\text { radius } \\
(\mu \mathrm{m})\end{array}$ & $\begin{array}{l}\text { N. (mean } \pm \text { SD) or } \\
\text { range number of } \\
\text { DGI into the CZ }\end{array}$ & $\begin{array}{c}\text { ML } \\
\text { at first year of life } \\
(\mathrm{TL}, \mathrm{cm})\end{array}$ & $\begin{array}{l}\text { Otoliths sampled } \\
\text { and } \\
\text { FL range }\end{array}$ & Area \\
\hline Morales Nin and Aldebert, 1997 & $1.15 \mathrm{~cm} /$ month & $162 \pm 43 \varnothing$ & $(43.9 \pm 19.7)$ & 16 & $\begin{array}{c}81 \\
10.5-20.7 \mathrm{~cm}(\mathrm{TL})\end{array}$ & Gulf of Lions \\
\hline Arneri and Morales-Nin , 2000 & 1.1-1.6 cm/month & - & - & 15 & $\begin{array}{c}145 \\
\text { 1.6- } 16.4 \mathrm{~cm}(\mathrm{TL})\end{array}$ & Central Adriatic \\
\hline Morales Nin and Moranta, 2004 & $1.2-2.5 \mathrm{~cm} /$ month & - & 63 & - & $\begin{array}{c}153 \\
2.5-25 \mathrm{~cm}(\mathrm{TL})\end{array}$ & Mediterranean Sea \\
\hline Kacher and Amara, 2005 & $0.72-0.74 \mathrm{~mm} /$ day & - & $(39 \pm 7, n=13)$ & 23.8 & $\begin{array}{c}107 \\
6-22 \mathrm{~cm}(\mathrm{TL})\end{array}$ & $\begin{array}{l}\text { Bay of Biscay and } \\
\text { Celtic Sea }\end{array}$ \\
\hline Palomera et al., 2005 & $0.15-0.19 \mathrm{~mm} /$ day & $(18.9-221.1) \varnothing$ & $6-26$ & - & $\begin{array}{c}71 \\
\text { 2.5-9.1mm (SL) }\end{array}$ & Mediterranean Sea \\
\hline Alvarez and Cotano, 2005 & $0.15-0.17 \mathrm{~mm} / \mathrm{day}$ & - & $3-40$ & - & $\begin{array}{c}40 \\
2-12 \mathrm{~mm} \text { (SL) }\end{array}$ & Bay of Biscay \\
\hline Morales Nin et al., 2005 & $1.8 \mathrm{~cm} / \mathrm{month}$ & $461.28 \varnothing$ & 64 & 23.7 & $\begin{array}{c}1 \\
13.5 \mathrm{~cm}(\mathrm{TL})\end{array}$ & Rearing conditions \\
\hline Belcari et al., 2006 & $1.3-1.7 \mathrm{~cm} /$ month & - & $(52 \pm 2)$ & 18.3 & $\begin{array}{c}579 \\
4-20 \mathrm{~cm}(\mathrm{TL})\end{array}$ & Tyrrhenian Sea \\
\hline This study & $\begin{array}{c}0.66 \pm 0.06 \mathrm{~mm} / \text { day } \\
\text { (mean } \pm \mathrm{sd}, \text { ). }\end{array}$ & $(89-212) \AA$ & $(51.2 \pm 8, n=27)$ & 25.2 & $\begin{array}{c}103 \\
3-25 \mathrm{~cm}(\mathrm{TL})\end{array}$ & NW Spanish Atlantic \\
\hline
\end{tabular}






Figure 1.- Map showing the survey area and the locations from which otoliths samples were obtained. 


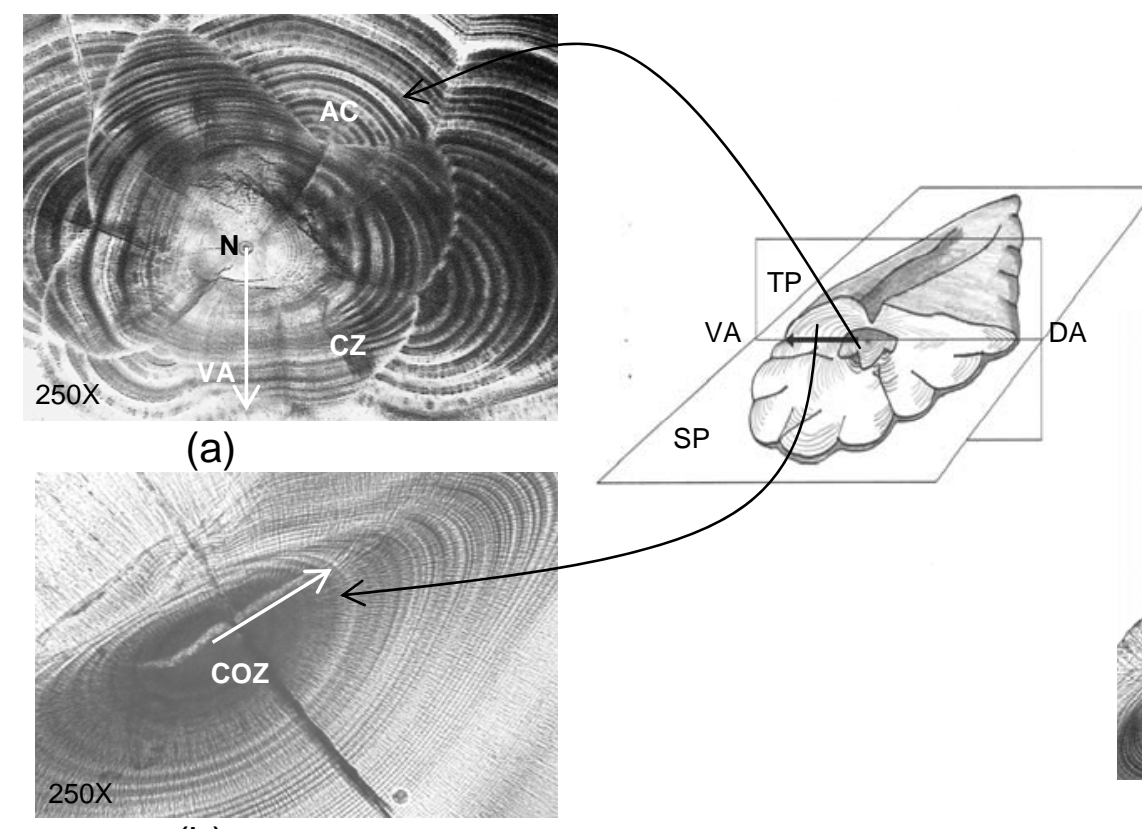

(b)

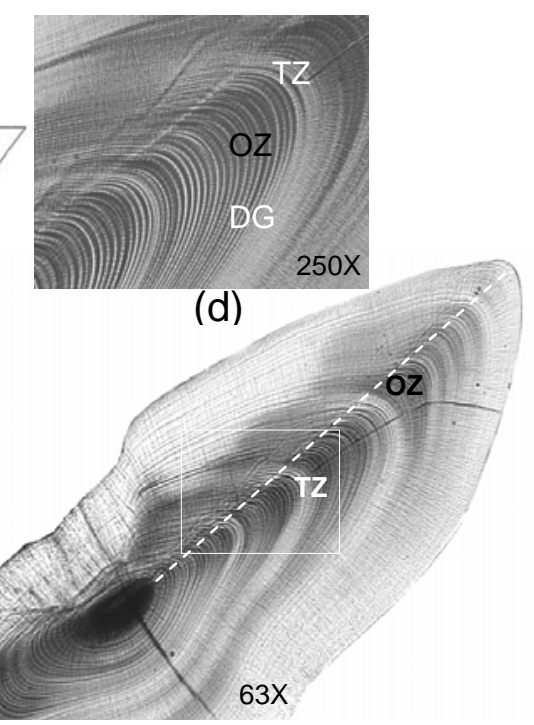

(c)

Fig. 2. Diagram showing the two sectioned planes of a hake otolith: saggital (SP) and transversal planes (TP) and the dorso-ventral axis (DA,VA). Photographs show: (a) saggital section showing the $\mathrm{CZ}$, with an arrow indicating the ventral axis used for counting (VA), the nucleus $(\mathrm{N})$, and accessory centers (AC); (b) transversal section showing the central opaque zone (COZ) where increments are indistinguishable; (c)view of the ventral axis chosen for radius measurement and growth increments along with changes in increment width; (d) detail of a sequence of growth increments (DG) showing translucent (TZ) and opaque bands (OZ). 


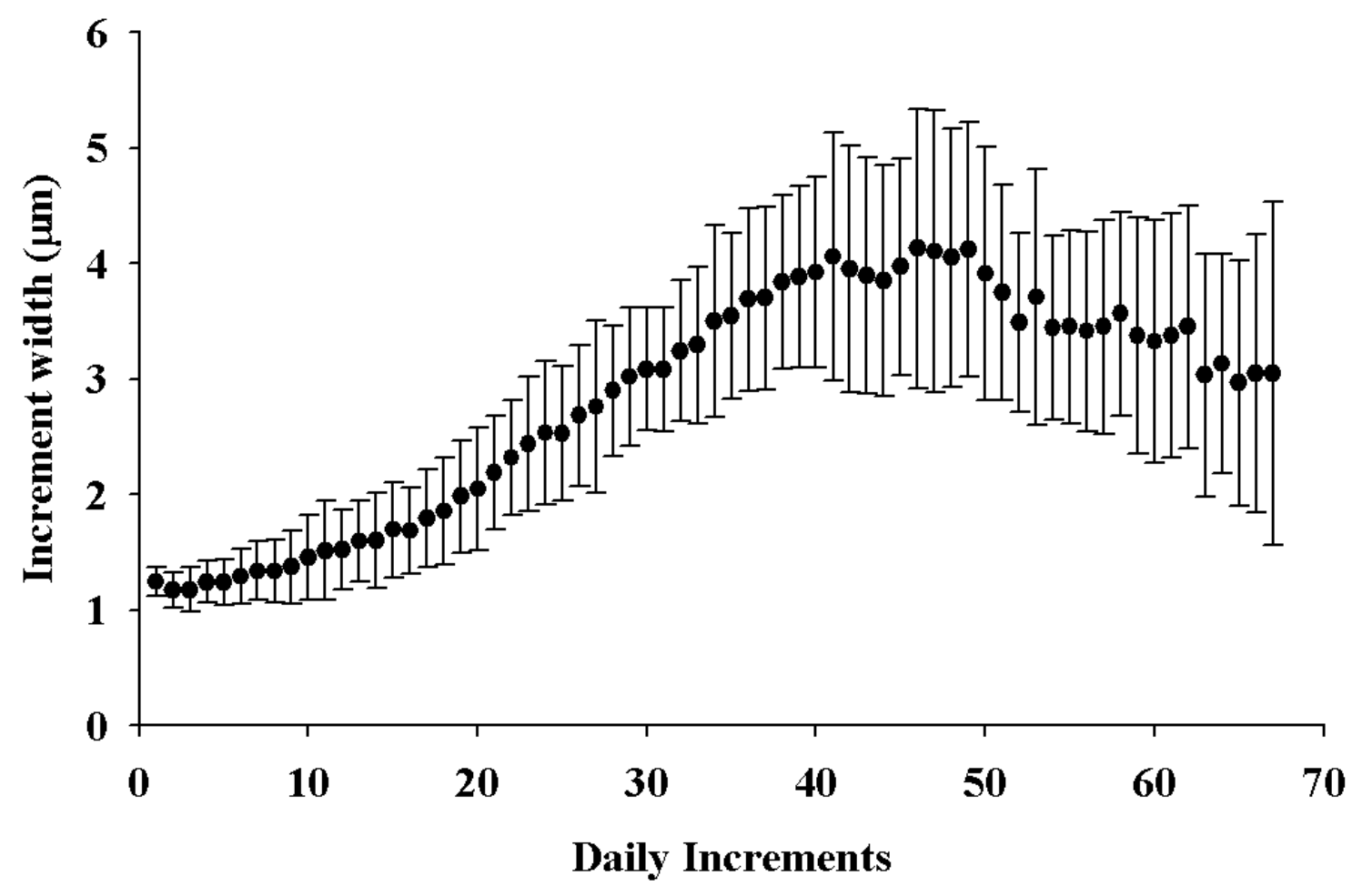

Figure 3.- Increments width (mean $\pm \mathrm{SD}$ ) within the $\mathrm{CZ}$ area of sagittal sections. 


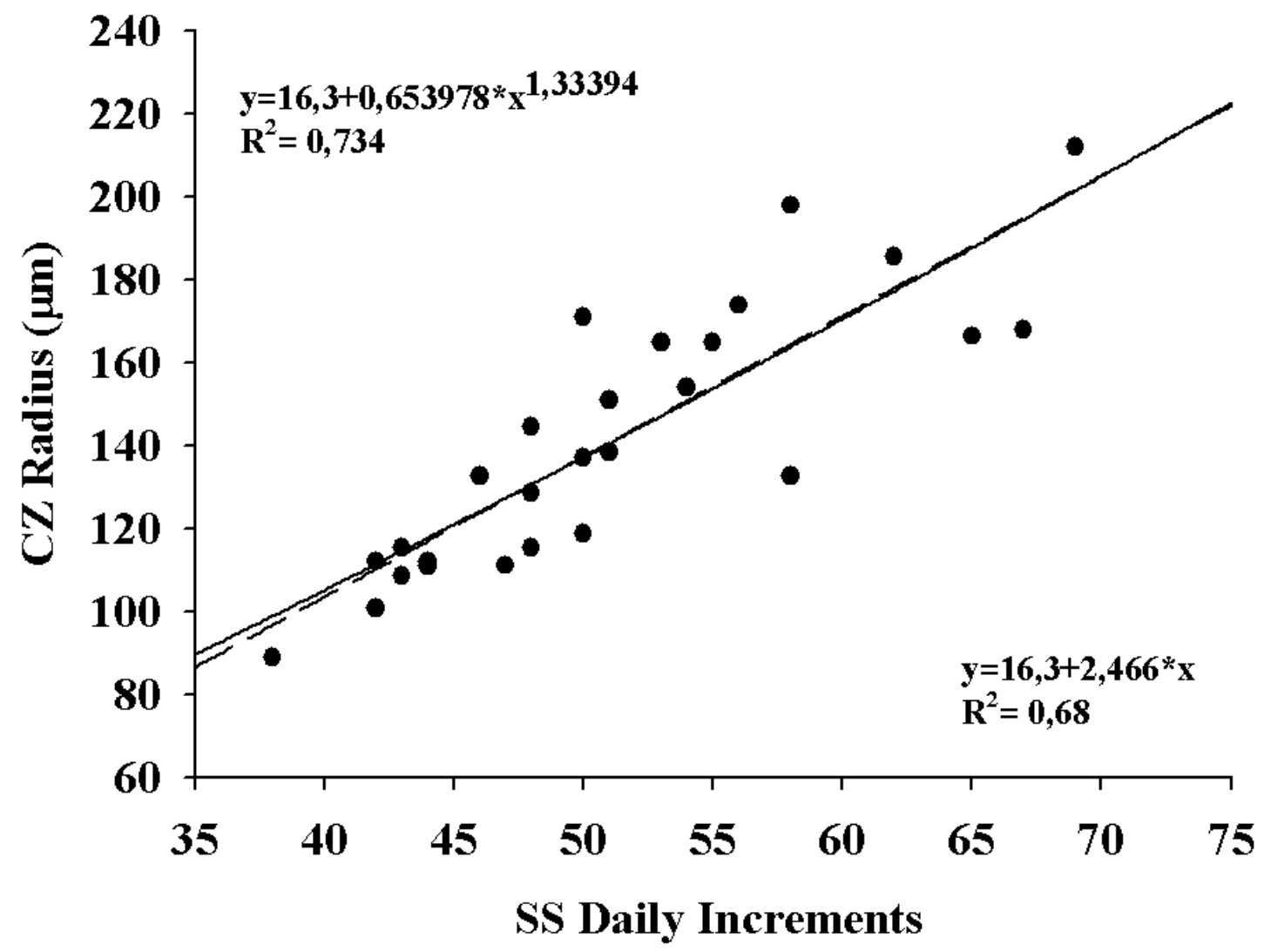

Figure 4.- Relationships (Power and Linear) between CZ radius and CZ daily increments of the sagittal section. 


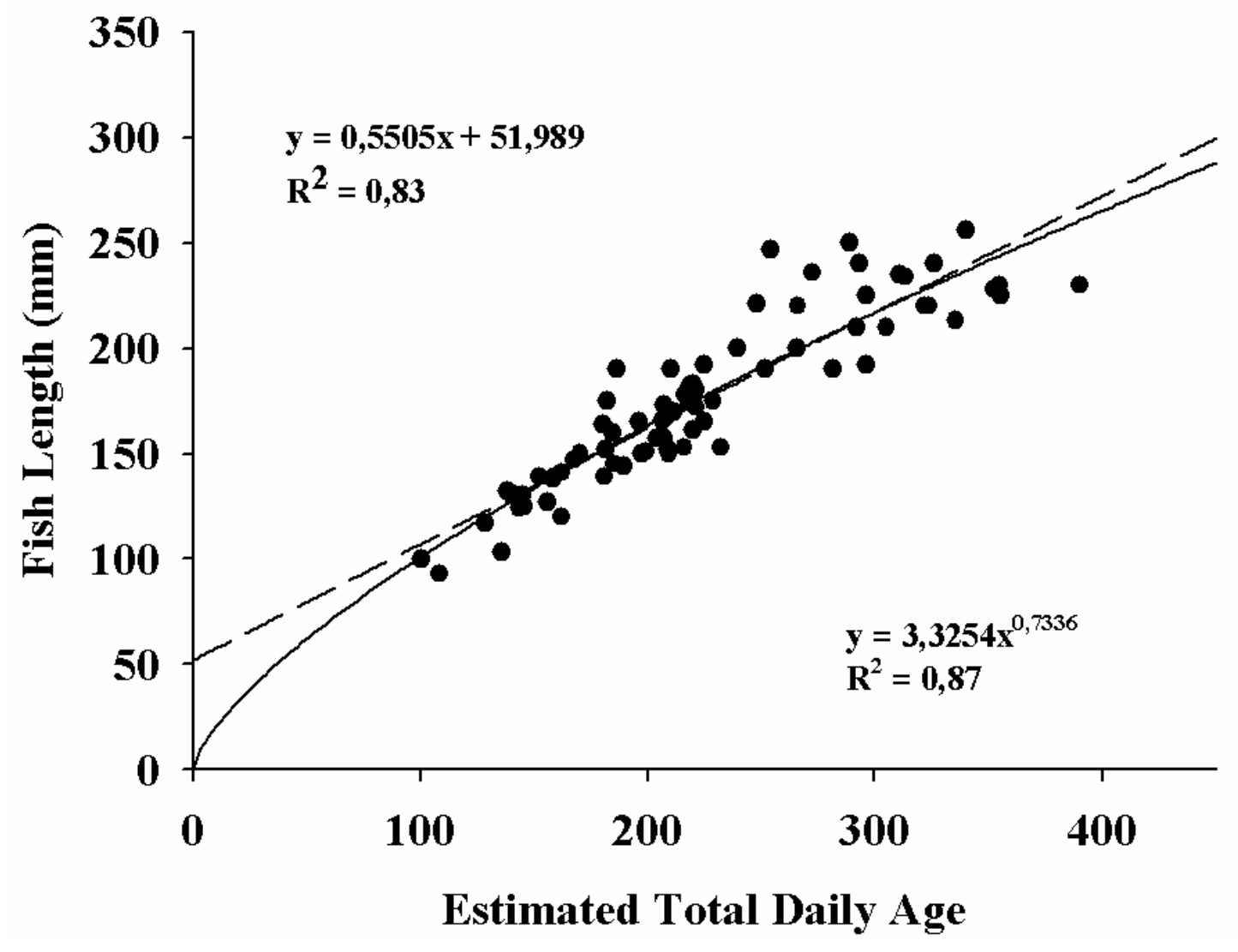

Figure 5.- Growth models (Power and Linear) of hake juveniles using estimated daily increments counts from TS and SS otoliths. 


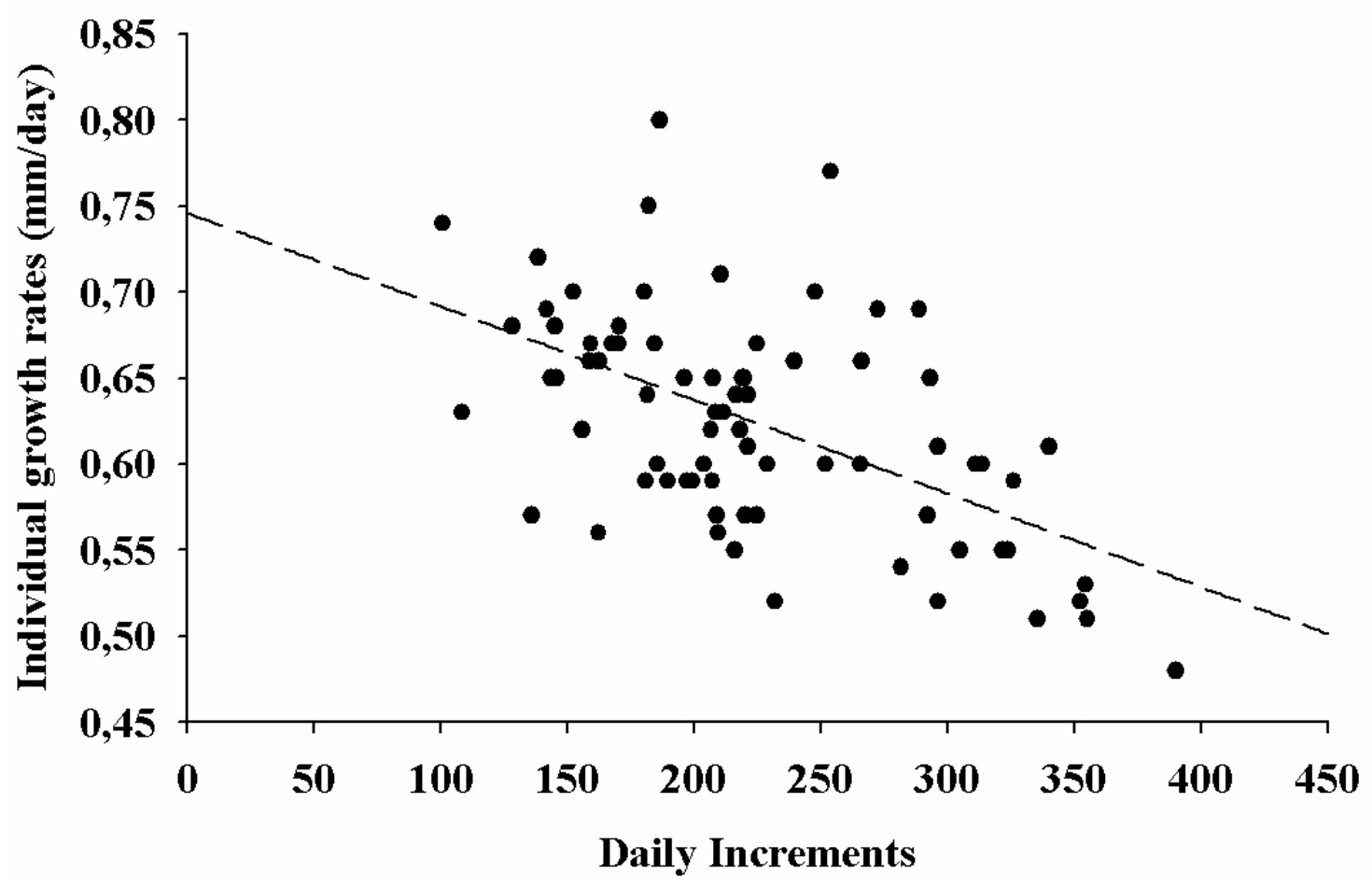

Figure 6.- Individual growth rates of hake juveniles by age. 


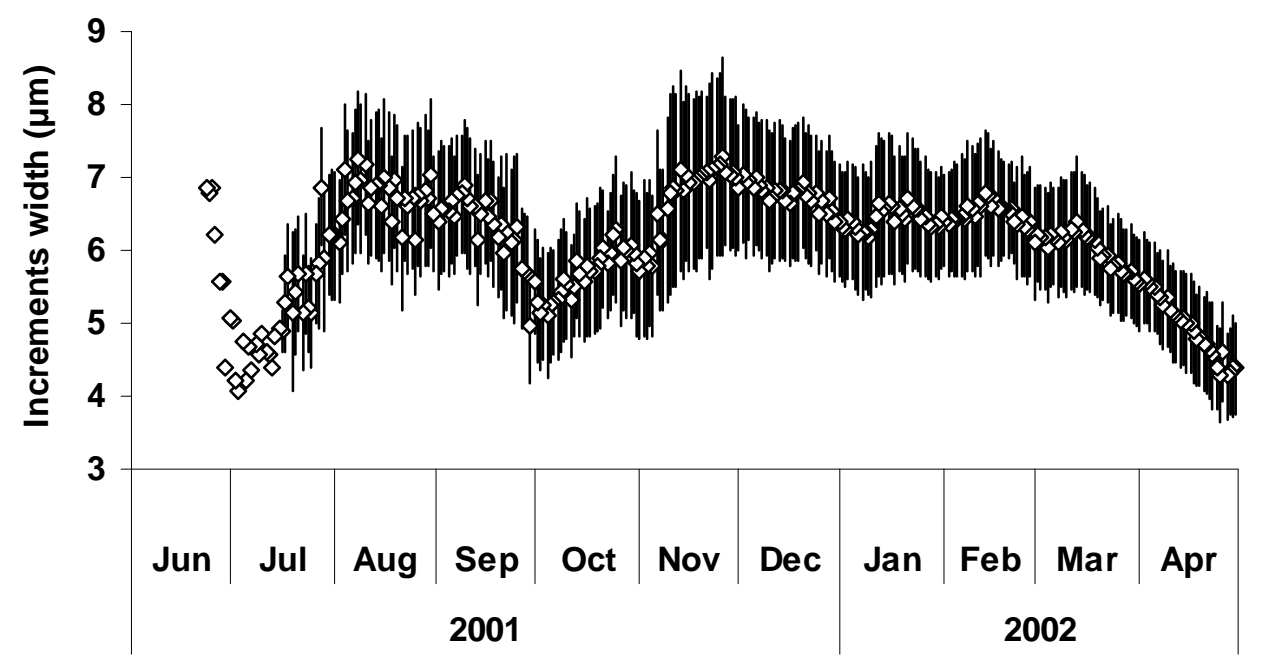

Figure 7.- Increments (mean widths) from individual capture date (most recent increment) to the COZ area of the transversal section. 